\title{
Zbrodnia jako dzieło sztuki? Na marginesie African Psycho Alaina Mabanckou
}

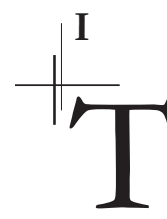

homas de Quincey, angielski autor doby romantyzmu, w jednym ze swych esejów zastanawia się nad pewnym zagadnieniem, którego kontrowersyjność ujawnia się już w samym tytule owych przemyśleń: On Murder Considered as One of the Fine Arts. Tekst opublikowany w 1827 roku i umieszczony we współczesnym zbiorze pism de Quinceya przetłumaczono na język polski pod tytułem O morderstwie jako jednej ze sžtuk. pięknych. Autor stwierdza tam:

Ludzie zaczynają dostrzegać, że wyrafinowane morderstwo pod względem kompozycji potrzebuje czegoś więcej niż tylko dwóch durniów: zabijającego i zabijanego, a także noża, sakiewki oraz ciemnego zaułka. Panowie, za nieodzowne przedsięwzięcia w tej dziedzinie uważa się obecnie sporządzenie projektu ogólnego, rozplanowanie usytuowania poszczególnych osób, rozmieszczenie świateł i cieni, nastrój poetycki i grę uczuć.

(Quincey 2002: 333)

Wszystkie elementy wymienione przez autora przywołują skojarzenia z pewną teatralizacją zbrodni - towarzyszą jej odpowiednie przygotowania, próby, ułożony zostaje scenariusz, a później gotowy już spektakl zachwyca odbiorcę. Dodatkowo de Quincey przywołuje kilka przykładów wydarzeń (zarówno morderstw, jak i np. pożarów). Jego zdaniem tego typu przypadki — po odjęciu ich moralnego wydźwięku — mogą przedstawiać sobą urok estetycznie satysfakcjonujący świadka wydarzeń. Mówi autor: 
(...) natomiast skłonność do krytycznej bądź estetycznej oceny pożarów i morderstw to rzecz powszechna. Gdy trafisz na spektakl ogromnego pożaru, pierwszym twym odruchem będzie niewatpliwie pomoc w jego gaszeniu. (...) W wypadku pożaru trawiącego własność prywatną współczucie dla nieszczęścia sąsiada powstrzymuje nas zrazu przed traktowaniem tego zdarzenia jako widowiska scenicznego. Ale być może, że pożar ograniczy się do budynków publicznych. I wtedy po spłaceniu naszej daniny w postaci ubolewania nad zdarzeniami, które uważamy za katastrofalne, w sposób nieunikniony i bez zahamowań zaczynamy odbierać je za każdym razem jako widowisko sceniczne. W swego rodzaju zachwycie z tłumu podnoszą się wo-

łania: „Wspaniałe! Cudowne!”

(Quincey 2002: 342-343)

Po takiej relacji można by podejrzewać de Quinceya o pewnego rodzaju predylekcje piromańskie, niemniej zdaje się także, że przedstawia on słusznie pewien pogląd na temat widowiskowości płomieni — również i współcześnie większe pożary przyciągają rzesze widzów, którzy napawają się widokiem destrukcyjnych działań ognia. Zatem to, co może przypominać dzieło sztuki w przypadku pożarów, to spektakularność. Przyjrzyjmy się jeszcze drugiej wspomnianej kategorii, mianowicie morderstwu — większą część rozważań Anglika stanowi opis dwóch ataków angielskiego zabójcy, Johna Williamsa, który działał w 1811 roku, a w swej „karierze” dokonał rzezi na siedmiu osobach w londyńskiej dzielnicy Wapping. W owym czasie ta seria zbrodni zaowocowała paniką w całej Anglii, nie tylko w Londynie, czemu przysłużyła się prasa, żyjąc przez kilka dni sensacyjnymi relacjami. Jakiś czas później de Quincey szczegółowo opisuje wydarzenia towarzyszące zbrodni, motywacje Williamsa, przebieg wypadków na podstawie relacji tych, którym udało się uratować przed zabójcą (prawdopodobnie autor konfabulował nieco, zgodnie z poetycką licencją romantycznego pisarza). Niemniej - przedstawia wyjątkową brutalność (Williams nie oszczędza nawet leżącego w kołysce trzymiesięcznego niemowlęcia, któremu miażdży czaszkę młotem) z jaką działał morderca i która tak przecież poruszyła ludzi głodnych wszelkich szczegółów dotyczących rzezi w Wapping. De Quincey podsumowuje kontrowersyjnie:

Pan Williams w oczach nas wszystkich podniósł rangę idealnego morderstwa. (...) Tak jak Ajschylos czy Milton w poezji, tak jak Michał Anioł w malarstwie, doprowadził on swój artyzm do szczytu wspaniałości (...).

(Quincey 2002: 333)

\section{II}

De Quincey, przedstawiając swój pogląd na paralelę między zbrodnią a dziełem sztuki, wskazał pewne kategorie, które towarzyszą morderstwu, ale odnaleźć można je również i w sztuce. Teatralizacja, urok, spektakularność, brutalność ukazywane w dziele to te ele- 
menty, które — przewrotnie — przyciagają potencjalnych odbiorców dzieł sztuki ${ }^{1}$. Esej angielskiego romantyka to interesujący kontekst podczas lektury ${ }^{2}$ jednej z powieści Alaina Mabanckou zatytułowanej African Psycho ${ }^{3}$ (2009), której akcja opisuje działania Grégoire’a Nakobomayo - młodego mieszkańca bliżej nieokreślonego dużego afrykańskiego miasta. Marzeniem i imperatywem mężczyzny staje się chęć odebrania komuś życia. Narracja prowadzona w pierwszej osobie porywa czytelnika w świat wewnętrznych walk i przemyśleń mordercy in spe. Powieść zaczyna się w dosadny sposób:

Postanowiłem zabić Germaine dwudziestego dziewiątego grudnia. Myślę od tym od tygodnia, gdyż, cokolwiek by o tym mówić, zabicie kogoś wymaga zarówno psychicznego, jak i materialnego przygotowania.

(Mabanckou 2009: 11)

Od razu znamy główną oś fabularna, która rozpięta jest między czterema częściami powieści: Mój idol i Wielki Mistrz. Angoualima, Dziewczyna w bieli, Zabić Germaine, Zabójstwo. Każda z nich pogłębia rys biograficzny i psychologiczny bohatera, a także opisuje jego kroki na drodze do zapowiedzianego na wstępie pomysłu - dokonania morderstwa. Część pierwsza odzwierciedla niejako losy młodego terminatora w pracowni jakiegoś mistrza. Poświęcona jest problemowi poszukiwania mentora przez Grégoire’a, który odnajduje go w najsłynniejszym mordercy własnego, niewymienionego z nazwy, kraju — Angoualimie. Biografia i legenda przestępcy, który lubował się w odrzynaniu głów swoich ofiar i okaleczaniu ich ciał, jest dla bohatera nadzieją na własne powodzenie. Nakobomayo odnajduje bowiem w swojej własnej historii wiele podobieństw do dziejów Angoualimy — obaj urodzili się w tej samej biednej dzielnicy i nie znali swych rodziców. Bohater kreśli szereg elementów, które łączą go z jego Wielkim Mistrzem, jak zwykł o nim mówić. Przekonuje sam siebie: „Tak, byłem do niego podobny. Nie fizycznie, ale przez wielkie upodobanie do samotności, którą pielęgnował, oraz fakt, że jego także rodzice nie uznali i porzucili na wielkim skrzyżowaniu życia (...)" (Mabanckou 2009: 19-20).

Bohater pragnie nie tyle dorównać w zbrodniczym kunszcie swemu Mistrzowi, co życzyłby sobie zostać uznanym przezeń za duchowego syna i spadkobiercę talentu. Na tle Angoualimy Nakobomayo przedstawia swoje zbrodnicze „wprawki”, niczym uczeń

1 Choćby dwa cytaty poświadczają te rozpoznania: 1 . na gruncie malarstwa — „Kto zna się dobrze na malarstwie, zobaczy u Michała Anioła grozę jego sztuki, a w jego postaciach cierpienie i uczucia, jakie nikt inny tylko on potrafił wyrazić”, zob. Vasari 1988: 157; 2. na gruncie literatury — „Naoczność, spektakularność, właśnie teatralność w eksponowaniu zmysłowych postaci zła — oto jakości, które zwracają uwagę (...)", zob. Hanusiewicz 2006: 40.

2 Kontekst, który może towarzyszyć wszystkim czytelnikom powieści, wydanej przez wydawnictwo Karakter, na czwartej stronie okładki umieszczono bowiem właśnie cytat z eseju de Quinceya.

3 Jako że autor jest mało rozpoznawalny w Polsce, pozwolę sobie przywołać krótką notę biograficzna Mabanckou urodził się w 1966 r. w Kongu-Brazzaville, jest piszącym po francusku kongijskim pisarzem i poeta. W trakcie studiów wyemigrowal do Francji, a później do Stanów Zjednoczonych. W Polsce nakładem wydawnictwa Karakter ukazały się cztery jego powieści, skupiające się na ukazaniu afrykańskiego świata zarówno na Czarnym Kontynencie (Jutro skończe dwadzieścia lat, Kielonek, African Psycho), jak i obrazu afrykańskiej diaspory w Paryżu (w powieści Black bazar). Więcej o biografii zob. Malela 2012: 251 oraz Czubrowska 2010: 148. 
pod patronatem rzemieślnika. Największe osiagnięcia jego młodości to przede wszystkim wczesne bójki z rówieśnikami, uliczna brutalność, którą sam okazuje i której jest ofiarą. Niemniej Grégoire, będąc jeszcze dzieckiem, dokonuje swojej pierwszej poważniejszej próby okrucieństwa. Ma do tego sposobność, kiedy jako kilkulatek zostaje przygarnięty przez dobrze sytuowaną rodzinę, która ma już własnego syna. Ten właśnie starszy chłopak pewnego razu usiłuje wykorzystać seksualnie młodszego od siebie Grégoire’a, jednak temu udaje się uniknać niebezpieczeństwa, a podczas ucieczki okalecza swego przybranego brata, pozbawiając go oka. Później jeszcze główny bohater usiłuje — dosłownie zatłuc młotkiem pewnego miejskiego notariusza (z tego czynu kandydat na mordercę jest wyjątkowo dumny, bowiem media przypisały go Angoualimie, jego Mistrzowi). Ponadto Nakobomayo czytuje literaturę, uczestniczy (jako obserwator) w procesach o morderstwa i snuje marzenia o zabójstwach:

(...) myślę, że gdybym mógł zabić wszystkie kobiety na Ziemi, zacząłbym od matki, gdyby tylko ktoś zechciał mi ją wskazać, choćby i teraz. Wyrwałbym jej serce twarde jak głaz, upiekł na palenisku w warsztacie i zjadł z batatami, oblizując palce i patrząc na resztę jej gnijącego ciała...

(Mabanckou 2009: 20).

Ta część powieści skupia się na rozwoju psychicznym bohatera, jego dążeniu do tego, by zasłużyć na szacunek Wielkiego Mistrza, na jego rozterkach wewnętrznych. Wyłaniaja się w tej części też dwa konteksty stereotypowo charakterystyczne dla młodych ludzi, którzy pragną wielkości. Mówi Grégoire: „zabójca musi w czymś przewyższać zwykłego człowieka” (Mabanckou 2009: 13). Słowa te przecież równie dobrze mogły zostać wypowiedziane przez poszukującego nadczłowieczej mocy Raskolnikowa z powieści Fiodora Dostojewskiego. Autorefleksje narratora powieści mają też pewien sznyt nietzscheański. Nakobomayo wie, że „zbrodnia to nie kino. Zbrodnia to także nie powieść kryminalna" (Mabanckou 2009: 145) — trzeba mieć pewne nadludzkie predyspozycje, by dokonać czegoś prawdziwego i przerażającego, nie ma w działalności mordercy nic zmyślonego, rozrywkowego, jedynie prawda. Do tego dochodzi jeszcze kwestia kompleksu Herostratesa, który niewatpliwie wykształcił Grégoire. Ów Herostrates był szewcem, który zapałał nieodpartą żądzą zapisania się w jakiś sposób w historii — jego pomysłem na osiagnięcie wiecznej sławy było podpalenie w 356 roku przed Chrystusem świątyni Artemidy w Efezie, jednego z siedmiu cudów świata starożytnego, a w efekcie — zniszczenie go. Jako karę za tę zbrodnię miano wymazać imię Herostratesa z kart wszelkich pism, jednakże jeden historyk ominą ten zakaz — Teopomp z Chios ,zachował go w swej historii, jak zachowana jest mucha w bursztynie" (Elder 2007: 439). Marzenia o nieśmiertelnej sławie to częste — jak się wydaje — pragnienia artystów, Grégoire, adept sztuki dość oryginalnej, jaką stanowi morderstwo, także wykazuje podobne skłonności - chce zostać zapamiętany bez względu na zbrodniczość własnych działań.

Pierwsza część książki kończy się dość symbolicznie — główny bohater ogląda program, w którym zaproszeni goście — dziennikarze i specjaliści w dziedzinie kryminologii — naigrywają się z Angoualimy. Oburzony Nakobomayo dzwoni do studia i, podając 
się za swego mistrza, grozi śmiercią zgromadzonym w studio. Program natychmiast zostaje przerwany, a jego uczestnicy korzą się przed Grégoire'em-Angoualimą, a sam bohater niejako staje się swoim idolem, przeistacza się w niego. Ma to swój fabularny oddźwięk część druga książki przedstawia pierwszą poważną próbę mordu — tytułowa „dziewczyna w bieli” jest pielęgniarka, którą Grégoire napada, próbuje zgwałcić i zabić, nie udaje mu się to jednak. Załamany swoim „dyletanctwem”, znajduje mimo wszystko w tej sprawie pewną naukę:

Teraz wiem, co było nie tak z dziewczyną w bieli. Morderstwo przez przypadek zapewne istnieje, ale już w to nie wierzę. Żeby odnieść sukces, trzeba silnej woli i, powtarzam, wielu przygotowań. Chyba że, rzecz jasna, ma się wyjątkowy dar jak mój idol Angoualima.

(Mabanckou 2009: 109)

Coraz wyraźniej dochodzi do Grégoire’a fakt, że mordercą — podobnie jak i malarzem, rzeźbiarzem, poetą — nie zostaja przypadkowi ludzie. Improwizacje skuteczne i doskonałej jakości nie zdarzają się każdemu, trzeba być jednostką wybitną — jak jego Mistrz — by móc sięgnać po najwyższe trofeum, jakim jest godne podziwu dzieło. Pod takimi wnioskami chętnie podpisałby się prawdopodobnie de Quincey, dopatrujący się w zbrodni czegoś więcej niż przypadku.

W części trzeciej, Zabić Germaine, akcja skupia się na kolejnych pomysłach bohatera na to, jak zabić tytułową Germaine — prostytutkę, która przygarnął do swego domu. Myśl o nadchodzącej realizacji własnego morderczego przedsięwzięcia nie daje Grégoire’owi spokoju:

Zamknięty w warsztacie, przestałem zajmować się autem kuzyna mera dzielnicy Picie-wody-to-idiotyzm, choć było to ważne i pilne zlecenie. Obejrzałem uważnie nóż, którym miałem popełnić zbrodnię. Zacząłem sobie wyobrażać, jak ostrze przecina skórę Germaine i dziurawi jelita. Już widziałem, jak zgrzytając zębami, wbijam go po trzonek. Uśmiechnąłem się, bo ten pomysł nagle mi się spodobał.

(Mabanckou 2009: 138)

Coraz ważniejsza staje się także relacja między uczniem a jego mistrzem. Grégoire prowadzi bowiem wewnętrzne monologi z Angoualima, który przezywa swego ucznia „Kanciastym Łbem". Nakobomayo zdaje mu relacje ze swych zbrodniczych działań, opisuje swoje problemy i plany na przyszłość, szuka u niego rady. Odwiedza także grób swego Mistrza i quasi-modlitewnym stylu szuka u niego posłuchu. „I tam, przysięgam wam, jakby to były czary, Wielki Mistrz zbrodni zjawia się przede mną równie charyzmatyczny jak w czasach swej chwały" (Mabanckou 2009: 12). Bohater w zasadzie czci swego opiekuna duchowego jak bóstwo, pragnie złożyć mu ofiarę z krwi zamordowanej przez siebie istoty ludzkiej: 
(...) oto ukazał mi się Wielki Mistrz, Imponujący, Boski, Majestatyczny, Potężny, Wzniosły (...), ale natychmiast spuściłem wzrok, wszak ta mityczna, charyzmatyczna postać to mój własny Bóg.

(Mabanckou 2009: 120)

Ostatnia część powieści, Zabójstwo, ma stanowić ten fragment dziejów Grégoire’a, kiedy w końcu uda mu się stworzyć dzieło godne jego Mistrza — zamordować Germaine. Ostatecznie okazuje się jednak, że plan bohatera nie spełnia się, dziewczyna zostaje bowiem w tym dziwnym i niebezpiecznym mieście zabita przez kogoś innego. Uczeń nie jest godny praktykować u swego nauczyciela. Angoualima, zażenowany niepowodzeniami bohatera, przestaje odpowiadać w rozmowach prowadzonych przez Grégoire’a z jego własna zaburzoną jaźnią. Nieudane dzieło, które mogło razić brutalnością i spektakularnością bo takie znamiona potencjalny czyn zdradza - nie zostało poddane zgorszonym zachwytom społeczeństwa, a Grégoire nie zdobył sławy, o której marzył. Sam Mabanckou tak podsumowuje swojego bohatera:

Punktem wyjścia była prawdziwa historia: w Kongo rzeczywiście działał seryjny zabójca — Angoualima. Wokół jego postaci narosło wiele legend. Mówiono, że miał dwie głowy, dwa członki, parę oczu z tyłu głowy... Żyliśmy w strachu, że spotkamy go kiedyś na swej drodze. W dniu, w którym zginął, Kongo było szczęśliwe. Ale byli również tacy młodzi przestępcy, którzy chodzili na jego grób, aby z nim rozmawiać, modlić się do niego, przejać jego potęgę i moc. W African Psycho bohater, młody człowiek, postanawia być silniejszy od niego. Chciałem pokazać, w jaki sposób, stopniowo, afrykańskie społeczeństwo wydało na świat takie monstra, które jeśli tak to można ujać, lśnią swym nieudacznictwem ${ }^{4}$.

(Mabanckou i Bonowicz 2009: 145)

\section{III}

Dziejów Grégoire’a Nakobomayo z powieści African Psycho z 2006 roku nie da się nie powiązać z dziejami Patricka Batemana z powieści American Psycho, którą opublikował w 1991 roku Bret Easton Ellis. Filiacja oczywiście zawarta jest w tytule, bez niej bowiem wcale nie byłoby tak łatwo odnaleźć nici łączącej obu bohaterów. Dzieła te są skomunikowane ze sobą i stają w parze wobec zagadnienia przemocy jako kategorii estetycznej. Bohaterami obu powieści są skrajnie odmienni mężczyźni — przy czym rozbieżności te uwidaczniają się zwłaszcza na płaszczyźnie socjologicznej i kulturowej. Skonfrontowanie obu tekstów ukazuje postaci ukształtowane w drastycznie różny sposób, które mają jednak pewną cechę wspólną, a jest nią, mówiąc nieco pompatycznie, zew krwi. Obaj autorzy skupiają się bowiem na pewnej — czy to wrodzonej, czy nabytej — cesze, mianowicie

4 W wywiadzie powraca także wątek Mabanckou jako kongijskiego pisarza frankofońskiego i wiążącej się z tym interpretacji postkolonialnej jego dzieł, więcej o tym problemie: Porra 2005. 
żądzy krwi, stającej się głównym napędem podejmowanych przez bohaterów działań. W obu powieściach głównym postaciom towarzyszy ewidentna tendencja do gloryfikowania brutalności, zachwytu czynem zbrodniczym. Zwłaszcza tekst Ellisa, uznany za skandaliczny i wpisany na swego rodzaju indeks ksiag zakazanych, podejmuje problem estetyzacji perwersji i przemocy. Oto kilka cytatów, które to odzwierciedlają:

— Wyj, maleńka — nalegam. — Otwórz buzię. — Pochylam się niżej i dotykam jej włosów. (...) zdejmuję rękawiczkę, otwieram jej usta i obcinam nożyczkami język, który z łatwością wyciągam z gardła i kładę na dłoni. Jest

ciepły, krwawi (...).

(Ellis 2015: 321)

Wirujące zęby rozszarpują ciało, mięśnie, ścięgna i kości z taką szybkością, że zanim zmarła, widziała, a przynajmniej mogła widzieć, jak odrzucam nogi odcięte od tułowia — w zasadzie przeciąłem ją na wysokości bioder, a nogom towarzyszy to, co zostało z poranionej pochwy. (...) Nie zastanawiając się, czy jeszcze oddycha, wyłupuję jej palcem oczy. (...) Po kilku minutach kość udowa i lewa kość szczękowa dziewczyny pieką się w piekarniku (...).

(Ellis 2015: s. 426-427)

Cytaty te poddano milczacej cenzurze — najobrzydliwsze elementy narracji zostały wycięte. A cała książka, która przedstawia życie zblazowanego dwudziestoszcześciolatka z grupy nowojorskich yuppies, jest nimi nasycona. Sam Ellis twierdził, że książka w dosadny sposób przedstawia krytykę amerykańskiego społeczeństwa ${ }^{5}$.

Co nie dziwi, książka wywołała skandal:

Bohater American Psycho to sfrustrowany yapiszon, który rozładowuje stres, mordując bestialsko przypadkowe ofiary. Gdy Ellis dostarczył maszynopis wydawcy (firmie Simon\&Schuster), ten zerwał z nim umowę i zażądał zniszczenia powieści. Ellis zaniósł więc American Psycho do konkurencyjnego wydawnictwa Vintage Books, które wydało książkę jako pornograficzny paper back. I wtedy rozpętała się burza.

5 Także i w komentarzach podkreśla się taki socjologiczny wymiar powieści: „Innymi słowy, wynaturzenie, dewiacja i perwersja w American Psycho nie są autorskim kaprysem, lecz wynikają z konsekwentnie realizowanego zamysłu i — na innej płaszczyźnie — stanowią finalny efekt egzystencji wypranej z jakichkolwiek pozytywnych doświadczeń i doznań, zorientowanej — jakby powiedział Erich Fromm — nie ku życiu, lecz ku śmierci" (Wach 2010: s. 86). Najoryginalniejszą koncepcją jest jednak chyba próba odniesienia powieści Ellisa do literackiego gotyku, zob. Mardsen 2013. Co do powieści Gangrena — powstała recenzja tej książi, którą zatytułowano - co znamienne — Polish Psycho (Czapliński 2005). 
Narodowa Organizacja Kobiet nawoływała do bojkotu, krytycy pisali o sadystycznym arcydziele, a Ellis otrzymywał anonimowe listy i telefony z pogróżkami. Doszło do tego, że wydawca przerwał trasę promocyjną z obawy

o życie autora.

(Ziębiński 2016: 116)

Książka okazała się wielkim sukcesem, podobnie jak bazujący na powieści film z Christianem Bale’em w roli głównej. Obraz ukazał się w dwóch wersjach — kinowej i reżyserskiej, bardziej brutalnej (American Psycho, reż. M. Harron, USA, 2000). Powracając jednak do Grégoire'a - wydaje się, że Bateman z American Psycho był wszystkim tym, czym chciał zostać bohater Alaina Mabanckou. Można chyba też śmiało postawić znak równości między Batemanem i Angoualima — ich rzezie, bo już nawet nie mordy, miały wszystkie te cechy, które wskazał de Quincey jako interesujące dla odbiorcy. Grzegorz Wysocki przewrotnie kończy swój artykuł, poświęcony powieści Mabanckou:

Gdyby Patrick Bateman wielkodusznie zgodził się na spotkanie z kimś tak mało znaczącym — prawdopodobnie wyśmiałby Kanciastego Lba i zrobił to jeszcze mniej subtelnie niż Angoualima. Bez dwóch zdań: „American Psycho” à rebours. Amerykański pierwowzór doczekał się godnego, choć przewrotnego i szyderczego, następcy.

(Wysocki: 2016)

Teatralizacja, urok, spektakularność i brutalność — wszystkie te cechy odnaleźć można w powieści Mabanckou, mimo że bohater ostatecznie mordercą nie zostaje, choć taki cel przyświeca mu przez całą książkę — cóż, nie każdy może być artystą, nawet w zakresie tak specyficznej sztuki, jaką jest zbrodnia.

\section{Michat Rozmyst}

Doktorant literaturoznawstwa w Katedrze Literatury Oświecenia i Romantyzmu Instytutu Filologii Polskiej w Katolickim Uniwersytecie Lubelskim Jana Pawła II. Główne zainteresowania badawcze: literatura romantyzmu polskiego, kwestie mitograficzne w literaturze, kultura ludowa Słowian. Sekretarz redakcji pisma „Zagadnienia Rodzajów Literackich”. Autor monografii Mistrz Twardowski w romantyzmie. Próba mitobiografii (Lublin 2016). 


\section{Bibliografia}

Czapliński Przemysław (2005), Polish Psycho, „Pogranicza”, nr 3.

Czubrowska Anna (2010), Multikulturowy patchwork Mabanckou, „Arterie”, nr 3.

Elder Edward (2007), Hero'stratus [w:] A Dictionary of Greek and Roman Biography and Mythology, ed. W. Smith, vol. 2, IB Tauris \& Co, London-New York.

Ellis Bret Eeaston (2015), American Psycho, przeł. J. Polak, vis-a-vis/Etiuda, Kraków.

Hanusiewicz Mirosława (2006), Uroda złła. Nad poematem O zabiciu młodziankón [w:] Wobec romantyzmu. Studia i sұkice ofiarowane Profesor Danucie Zamacińskiej-Paluchowskiej, red. M. Lukaszuk, M.Maciejewski, TN KUL, Lublin.

Mabanckou Alain (2009), African Psycho, przeł. J. Giszczak, Karakter, Kraków.

Mabanckou Alain (2009), To, na co patryymy, to słowa, rozm. przepr. Wojciech Bonowicz, przeł. O. Hedemann, „Znak”, nr 12.

Malela Buata Bundu (2012), Posture controversée et discours littéraire Miano et Mabanckou dans le dispositif médiatique, „Romanica Silesiana”, nr 7.

Mardsen Stevie (2013), „It's all unclear”: The Reality” of Bret Easton Ellis's „American Psycho” and its Position Within the Literary Convention of Contemporary Gothic Fiction [in:] Fatal Fascinations: Cultural Manifestations of Crime and Violence, ed. S. Bray, G. Preher, Cambridge Scholars Publishers, Cambridge.

Porra Véronique (2005), De la marginalité instituée à la marginalité déviante ou que faire des littératures africaines d'expression française contemporaines?, „Revue de Littérature Comparée”, nr 2.

Quincey Thomas de (2002), O morderstwie jako jednej ze sztuk pieknych [w:] tenże, Wyznania angielskiego opiumisty $i$ inne pisma, przeł. M. Bielewicz, Czytelnik, Warszawa.

Vasari Giorgio (1988), Żywoty najsławniejszych malarzy, rzę́biarzy i architektów, przeł. K. Estreicher, t. 7, PWN, Warszawa-Kraków.

Wach Jarosław (2010), Anatomia nienawiści. Psychopatologia i destruk.cja w „Gangrenie” Dawida Kornagi oraz, „American Psycho” Breta Eastona Ellisa, „Akcent”, nr 2.

Wysocki Grzegorz (2016), Alain Mabanckou, „African Psycho”, http://www.dwutygodnik.com/ artykul/524-alain-mabanckou-african-psycho.html [dostęp: 1.03.2016].

Ziębiński Robert (2006), Skandalista Easton Ellis, „Newsweek Polska”, nr 13.

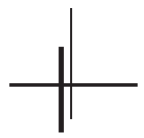

